\title{
Guidelines on pediatric day surgery of the Italian Societies of Pediatric Surgery (SICP) and Pediatric Anesthesiology (SARNePI)
}

\author{
Ugo de Luca ${ }^{1 *}$ (D), Giovanni Mangia ${ }^{2}$, Simonetta Tesoro ${ }^{3}$, Ascanio Martino ${ }^{4}$, Maria Sammartino ${ }^{5}$ \\ and Alessandro Calisti ${ }^{6}$
}

\begin{abstract}
The Italian Society of Pediatric Surgery (SICP) together with The Italian Society of Pediatric Anesthesia (SARNePI) through a systematic analysis of the scientific literature, followed by a consensus conference held in Perugia on 2015, have produced some evidence based guidelines on the feasibility of day surgery in relation to different pediatric surgical procedures. The main aspects of the pre-operative assessment, appropriacy of operations and discharge are reported.
\end{abstract}

Keywords: Day surgery, Outpatient, Day case surgery, Ambulatory surgery, Guidelines

\section{Background}

Pediatric Day Surgery has become increasingly prevalent in western countries during recent years. Pediatric procedures elegible for day surgery have also been more frequently produced mainly because of the improvement in minimally-invasive surgical techniques, the development of new general anesthetic drugs and the wider use of regional anesthesia. Nowdays, $60 \%$ to $80 \%$ of operations in a modern pediatric hospital are performed on a day surgery basis. The major advantages of this trend consist in the lessening of psychological stress for children and parents and the reduction in hospital costs, frequency of nosocomial infections and length of surgical waiting lists. In order to evaluate the surgical procedures suitable for day surgery with the same level of reliability as applies in the case of in-patient operations, the Italian Society of Pediatric Surgery (SICP) together with the Italian Society of Pediatric Anesthesia and Resuscitation (SARNePI) have produced EBMguidelines concerning pediatric day surgery.

\section{Methods}

The literature was examined by means of specific "queries" in the database of NCBI, the National Guidelines Clearinghouse, the Cochrane Library, Medline Complete

\footnotetext{
* Correspondence: ugo.deluca56@gmail.com

'Day Surgery Unit, Santobono-Pausilipon Pediatric Hospital, Napoli, Italy

Full list of author information is available at the end of the article
}

and Dynamed-Ebsco. The query "ambulatory surgical procedures”[Mesh] and (“"2010/05/01”[PDAT]: “2015/05/ 31"[PDAT]) and ("infant"[MeSH Terms] or "child"[MeSH Terms] or "adolescent"[MeSH Terms])) provided 391 items, which included 86 clinical trials and 31 reviews.

The Evidence Levels of the proofs and Grade of Recommendation were expressed according to the criteria defined in the Methodological Handbook provided by the National Programme for Guidelines promoted by the Istituto Superiore Sanità (ISS) with the cooperation of the CEVeAS of Modena [1] as reported in Table 1.

There are three main stages in day surgery: the pre-operative assessment, the surgical procedure and the discharge.

\section{Pre-operative assessment}

Children have been considered as ideal for day-case management because they usually have little co-morbidity and on account of the fact that many common pediatric operations are well suited for day surgery.

The pre-operative assessment must concern principally:

\section{Clinical factors}

Structured questionnaires completed and signed by the parents and by the pediatrician concerned, covering both social and medical history, are obtained during the pre-operative assessment. 
Table 1 The CEVeAS Scale of the level of evidence of the proofs and the grades of recommendation

\begin{tabular}{l} 
LEVEL OF EVIDENCE (LE) \\
\hline I Evidence obtained from several RCTs and/or reviews of RCT \\
II Evidence obtained from one RT adequately designed \\
III Evidence obtained from non randomized cohort studies with case/ \\
control or their methanalysis \\
IV Evidence obtained from case/control retrospective studies or their \\
methanalysis \\
V Evidence obtained from series of cases without control group \\
VI Evidences obtained from experts advice, from consensus conferences, etc. \\
GRADE OF RECOMMENDATION (GR) \\
A Surgical or diagnostic procedures are strongly recommended because \\
they are sustained by high level scientific evidence, even if not necessarily \\
of type I or II \\
B It is doubtful that the procedure must be always recommended but it \\
must be carefully considered \\
C There exists an element of uncertainty both in favor and against the \\
recommendation \\
D The procedure is not recommended \\
E The procedure is strongly ill-advised
\end{tabular}

ASA I-II children are suitable for outpatient treatments. ASA III patients are generally excluded, but may possibly be included for low grade surgical procedures.

Premature infants must be excluded if they are of less than 60 weeks post-conception age even if the risk of any postanesthetic apnoea is related to the grade of prematurity.

Pre-operative investigations (lab tests, $\mathrm{x}$-rays and ECG) are rarely performed according to recent guidelines but may be possibly be requested by the anesthesiologist or by the surgeon during their clinical and anamnestic evaluation. (Table 2).

\section{Socio-familial factors}

A responsible adult, preferably both parents, must be available to transport the child and to provide home assistance in the post-operative period. A telephone must also be available and the home hygiene condition must be satisfactory. Finally a primary care hospital must be accessible within $1 \mathrm{~h}$ travelling distance by car from the patient home. All these requirements can be summarized as parental/environmental adequacy.

\section{Surgical factors}

Over recent years the complexity of surgical procedures has increased, with a wider range of children being suitable for day surgery. This is mainly due to the development of minimal invasive surgery and new anesthetic drugs and techniques, the wider use of regional anesthesia and the improved postoperative pain management. Generally speaking, a surgical day-case procedure should last not more than $120 \mathrm{~min}$, without a high risk of post-operative bleeding or uncontrollable postoperative pain.

\section{Suitable surgical procedures Inguinal hernia and hydrocele}

Inguinal hernia and communicating hydrocele are both caused by a failure of obliteration of the processus vaginalis of the peritoneum. The majority of inguinal hernias in infants and children are indirect hernias with direct and femoral hernias only occasionally observed. All these hernias are appropriate for surgical treatment on a day surgery basis either with a traditional open approach (LE 4; GR A) or with a laparoscopic approach (LE 4; GR B) except for premature infants of less than 60 postconception weeks of age due to risk of postoperative apnoea (LE 3; GR E) [2-22].

\section{Undescended testis}

A congenital failure of the testis to reach the base of the scrotum after the third month of life requires surgical treatment, preferably if performed between 6 and 18 months of age. In particular, it is advisable to operate within the first year of life in the case of a higher position of the testicle (intrabdominal or intrainguinal) and within 18 months the case of an in extrainguinal lower position (pre-pubic, external inguinal ring or ectopic) (LE: 3; FR: B). A retractile testis does not need medical or surgical treatment, but require regular follow-up until puberty (LE: 3; GR: A). Orchidopexy can be carried out on a day surgery basis [23-29] either by an open technique (LE: 3; GR: A) or laparoscopically, in the case of an intra-abdominal testis (LE: 3; GR: B).

\section{Varicocele}

Varicocele is an abnormal dilation of the testicular veins in the pampiniformis plexus, more often (in 90\% of cases) of the left side, caused by venous reflux. Indications for surgical treatment consist in testicular hypotrophy (> 20\% of the contralateral size) and/or symptomatic varicocele (pain). All operations for the treatment of varicocele are based on the ligation or occlusion of the internal spermatic veins [30-36]. Inguinal or subinguinal microsurgical ligation, anterograd sclero-embolization and suprainguinal ligation, using open or laparoscopic techniques, are all suitable for day surgery (LE: 5; GR: A/B).

Indeed, it is safe to say that all inguinal procedures are suitable for day surgery. The low level of evidence in the scientific literature in this field is due to the absence of randomized trials. However this is counterbalanced by the higher grade of recommendation deriving from the widespread and consolidated clinical experience throughout the world in the last 30 years, summarized in certain relevant consensus documents, such as those produced by BAPS and AAPHA) [3-6]. 
Table 2 Pre-Operative phase

\begin{tabular}{|c|c|c|c|c|}
\hline Question & Advise & Evidence & $\begin{array}{l}\text { Grading } \\
\text { Recomandation }\end{array}$ & Literature \\
\hline $\begin{array}{l}\text { Family or Social Status } \\
\text { excluding Day Surgery }\end{array}$ & $\begin{array}{l}\text { Parents reluctant or unable to take care of the child in the post-operative } \\
\text { period at home. Poor domestic hygienic conditions. Lack of a telephone. } \\
\text { House more than } 1 \mathrm{~h} \text { travelling distance from an hospital provided with a } \\
24 \mathrm{~h} \text { emergency facility. Absence of public transport }\end{array}$ & V & A & [122-127] \\
\hline Newborns & $\begin{array}{l}\text { Full term newborns (Gestional Age Weeks }>38 \text { ) of less than } 1 \text { month are } \\
\text { excluded from Day Surgery. Exclusion should be preferably extended to at } \\
\text { least } 6 \text { months of age. Infants from } 2 \text { to } 6 \text { months age could be included } \\
\text { according to Structure Policy and Surgical Grading. }\end{array}$ & V & A & {$[18,128-131]$} \\
\hline ASA III Patients & $\begin{array}{l}\text { Normally excluded from Day Surgery. May possibly be eventually included } \\
\text { in relation to low surgical grading procedures. There needs to be, at any } \\
\text { rate, a prolonged observation post-operatively before discharge. }\end{array}$ & III & C & {$[132,133]$} \\
\hline $\begin{array}{l}\text { Patient with current Upper } \\
\text { Respiratory Infection (URI) }\end{array}$ & $\begin{array}{l}\text { Procedure must be postponed in relation to patients with major respiratory } \\
\text { symptoms. If there are mild or moderate symptoms the procedure should } \\
\text { be postponed if the child is of less than } 1 \text { year of age. In the case of older } \\
\text { patients the risk factors should be considered and the appropriacy of the } \\
\text { operation assessed in each case. }\end{array}$ & $\|$ & A & [134-136] \\
\hline Pre-Term & Infants PCA > 60 weeks. Clinically Stable. Anemia corrected. & $\|$ & A & {$[2,137-140]$} \\
\hline Evaluation of Timing & $\begin{array}{l}\text { No pre-anesthesia assessment much in advance. An assessment is advisable } \\
\text { shortly before the procedure. }\end{array}$ & V & B & [141-145] \\
\hline Lab Tests & $\begin{array}{l}\text { Routine Lab Tests in healthy patients older than }>1 \text { yr. have a low } \\
\text { predictive value }\end{array}$ & । & A & {$[146-151]$} \\
\hline Medical Records & $\begin{array}{l}\text { A parental anamnestic questionnaire is a good tool before any surgical } \\
\text { procedure. }\end{array}$ & IV & C & [152] \\
\hline Pre-operative Fasting & $\begin{array}{l}\text { The administration of clear fluids up to two hours before induction is } \\
\text { advised. This lower the residual gastric volume and raise } \mathrm{pH} \text {. }\end{array}$ & । & A & [153-156] \\
\hline $\begin{array}{l}\text { Prevention of Nausea and } \\
\text { Post-Operatory Vomiting } \\
\text { (PONV) }\end{array}$ & $\begin{array}{l}\text { PONV prevention requests a multifactorial approach that includes } \\
\text { pre-operative identification of risk factors (family history, age }>3 \text { yrs., } \\
\text { Strabismus Repair and ORL surgery). In patients at risk prophylaxis is } \\
\text { recommended (i.e.ondansetron } 0.05 \mathrm{mg} / \mathrm{kg}+\text { dexametason } 0.015 \mathrm{mg} / \mathrm{kg} \text { ). }\end{array}$ & I & A & {$[157,158]$} \\
\hline
\end{tabular}

To date, there has been some concern about discharging patients operated laparoscopically on the day of the surgery even in the presence of a good level of evidence, reported in large adult and pediatric series, suggesting the comparative safety of this choice $[9,18,19,25,27,30$, 34]. It would be desirable in the future to plan large multicenter randomized trials to better support the level of evidence of this common practice.

\section{SUITABLE FOR DAY SURGERY}

INGUINAL HERNIAS: LE: 4; FR: A

HYDROCELE: LE: 4; FR: $\mathbf{A}$

UNDESCENDED TESTIS LE: 3; FR: $\mathbf{A}$

VARICOCELE LE: 3; FR: A

TO BE EVALUATED IF SUITABLE FOR DAY SURGERY

LAPAROSCOPIC INGUINAL HERNIA LE: 4; FR: B

LAPAROSCOPY FOR INTRA-ABDOMINAL TESTIS LE: 3; FR: B

LAPAROSCOPIC VARICOCE LE: 3; FR: B

\section{NOT SUITABLE TO DAY SURGERY}

INGUINAL HERNIA IN PRETERM INFANTS < 60 PCW: LE: 3; FR: E

\section{Umbilical and alba hernias}

Common umbilical hernias after 3 years of life, as well as alba (epigastric) hernias are reported to be well managed as day surgery procedures (LE: 4; GR: A).

Rarer huge umbilical hernias (permagna hernias) of the infant must be considered as inpatient procedures because of possible respiratory problems following the reintegration into the abdomen of a large quantity of the bowel.(LE: 4; FR: D) [37-41].

\author{
SUITABLE FOR DAY SURGERY \\ UMBILICAL HERNIA (LE: 4; GR: A) \\ ALBA LINE HERNIA (EPIGASTRIC) (LE: 4; GR: A)
}

NOT SUITABLE FOR DAY SURGERY

PERMAGNA UMBILICAL HERNIA IN INFANTS (LE: 4; GR: D)

\section{Phimosis}

An absence of the retraction of the foreskin after the first year of life is called phimosis. Only scarring phimosis should be considered as true fhimosis (post- 
traumatic, due to chronic inflammation or to $\mathrm{BXO}$ ). Partial or total circumcision is the operation of choice, limiting plastic procedures, like Duhamel's, only to cases of light preputial stenosis occuring in older children during erection. Both surgical procedures (circumcision and preputial plasty) can be performed as day surgery. (LE: 5; GR: A) [4-6, 17, 41, 42].

\section{Buried penis}

A buried penis is a normal length shaft enclosed (buried) in prepubic fat. This can be the consequence of obesity, circumcision in an overweight child or the less frequently observed congenital abnormal fixation of the fascia and skin to the balanic sulcus instead of to the base of the penis. Surgical correction is indicated only for the congenital or the post-circumcision forms. (LE:5;GR:B) [18, 32, 43-45].

\section{Webbed penis}

An abnormal peno-scrotal junction, resulting in a ventral web, is not only an esthetic problem but it can involve a functional complication during erection. The common V-Y or multiple $\mathrm{Z}$ plasty are easily realized as day surgery procedures. (LE: 5; GR: A) [4, 5].

\section{Distal Hypospadia}

Glandular or distal shaft hypospadias are the most frequent (75\%) form of this common uro-genital malformation. Surgical corrections (MAGPI,TIPU,Mathieu) around the 15th month of life are all quite realizable with discharge on the same day either with or without a urethral catheter or stent. Parental adequacy and pain management may suggest the assistance regimen (as an in or outpatient). (LE: 3; GR: B) [46-52].

\section{SUITABLE FOR DAY SURGERY}

PHIMOSIS AND WEBBED PENIS (LE: 5; GR: A)

TO BE EVALUATED IF SUITABLE FOR DAY SURGERY

BURIED PENIS (LE: 5; GR: B)

DISTAL HYPOSPADIA (LE: 3; GR: B)

\section{Superficial pathologies}

Cysts, nevi and tumors, which reach the fascia or the skull periosteum may be managed on a day surgery basis, as well as embryonal remnants such preauricular sinus or cartilaginous tags. (LE: 5; GR: A) [6, 15, 17, 18, 53].

\section{Angiomas and lymphangiomas}

Small hemangiomas or lymphangiomas, if susceptible to surgical resection or laser photocoagulation as well as other superficial lumps, may be managed as outpatient procedures. This is also true in the case of larger masses where sclerotherapy is the treatment of choice (LE: 5; GR: A) [54-59].

\section{Lymphadenopathy}

Superficial lymphadenectomy and sentinel node biopsy can be performed as outpatient procedures (LE: 5; GR: A) $[6,15,17,18,53]$.

\section{Pilonidal disease}

The open surgical treatment of pilonidal disease is not recommended for day surgery (LE: 5; GR: D) but the primary closure after wide fistulas excision or punch biopsy fistulectomy can be managed as day surgery procedures (LE: 5; GR: B) [60-64].

\section{SUITABLE FOR DAY SURGERY \\ NEVI, TEGUMENTAL AND EPIFASCIAL LUMPS \\ (LE: 5; GR: A) \\ SURGICALLY RESECTABLE OR SCLEROSABLE HEMANGIOMA AND LIMPHANGIOMA (LE:5:GR:A) \\ SENTINEL NODE BIOPSY AND SUPERFICIAL LIMPHADENECTOMY (LE: 5; GR: A)}

\section{TO BE EVALUATED IF SUITABLE FOR DAY SURGERY}

PILONIDAL DISEASE PRIMARY CLOSURE OR PUNCH FISTULECTOMY (LE: 5; GR: B)

PILONIDAL DISEASE OPEN TREATMENT

(LE: 5; GR: D)

\section{Ankyloglossia (tongue-tie)}

Tongue-tie requires frenulotomy if it interferes with suction or causes speech problems. Within the first six-nine months frenulotomy can be carried out as office surgery.In relation to older infants a light and short general anesthesia, feasible as day surgery, is required (LE: 5; GR: A) [65-67].

\section{Diastema}

An excessive gap between superior teeth is called a distema and is frequently observed when the superior labial frenum is hypertrophic and inserted on the free edge of the gums. In this case, and mainly for esthetic reasons, a $\mathrm{z}$ plasty correction can be realized when the permanent dentition has been completed. (LE:5;GR:A) [6, 15, 17, 18, 53].

\section{Mucocele}

Mouth floor, labial and sublingual mucoceles are all resectable as outpatient procedures. Larger ranulas are more frequently treated with marsupialisation to prevent relapse. (LE:5;GR:A) [6, 15, 17, 18, 53].

\section{Cleft lip}

Several studies with good scientific evidence report the feasibility of cleft lip and anterior palate surgical correction with a day surgery regimen. (LE:3;GR:B). 
The decision depends mainly on the experience of the surgeons and their familiarity with these procedures [68-75].

\author{
SUITABLE FOR DAY SURGERY \\ TONGUE TIE \\ (LE: 4; GR:A) \\ DIASTEMA \\ (LE: 5; GR:A) \\ MUCOCELE \\ (LE:5;GR: A) \\ TO BE EVALUATED IF SUITABLE FOR DAY SURGERY \\ CLEFT LIP AND PALATE \\ (LE: 3; GR: B)
}

\section{Branchial anomalies}

Sinuses, cysts and fistulas of the second and third branchial arch can be excised as outpatient procedures (LE: 5; GR:A) whereas the resection of the first and fourth branchial arch cysts must be evaluated for overnight stay in hospital. (LE: 5; GR: B). Partial thyroidectomy is often necessary to remove a cyst of the 4th branchial arch and therefore an overnight stay in hospital is recommended (LE: 5; GR: C) $[6,15,17,18,53,76-78]$.

\section{Thyroglossal cyst}

The Sistrunk procedure involves the excision of the cyst or fistula together with the body of the hyoid bone and the suprahyoid duct as far as the foramen caecum. An accurate hemostasis during the procedure is essential and, when this rule is correctly applied the patient can be safely discharged on the day of the operation. This decision should be made taking into account the surgeon's experience and the duration and difficulty of the operation. (LE: 4; GR:B) [79-81].

\section{SUITABLE FOR DAY SURGERY}

2ND AND 3RD BRANCHIAL ARCH SINUSES, CYSTS AND FISTULAS

(LE: 5; GR: A)

\section{TO BE EVALUATED IF SUITABLE FOR DAY SURGERY}

1ST AND 4TH BRANCHIAL ARCH CYSTS

(LE: 5; GR: B)

THYROGLOSSAL DUCT CYSTS

(LE: 4; GR: B)

PARTIAL THYROIDECTOMY

(LE: 5; GR: C)

\section{Appendicitis}

Despite a good level of evidence in both adult and pediatric scientific literature reporting, the feasibility of non complicated appendectomies or interval appendectomies in day surgery, there is still uncertainty among surgeons about discharge on the day of surgery in such cases (LE: 3; GR:B) [82-87].

\section{Gallbladder diseases}

Gallbladder diseases in children are quite rare particularly if compared to adults. Laparoscopic cholecystectomy is the gold standard of treatment. The widespread diffusion of this procedure has produced a great number of high quality scientific studies (RCT) reporting the feasibility and safety of this procedure in day surgery.

In the pediatric field laparoscopic cholecystectomy is less frequently performed with a consequent reduction in the surgeon's experience and confidence. For this reason the pediatric consensus conference held in Perugia, despite the high quality of evidence (LE: 1), preferred to assign a grade of recommendation $\mathrm{B}$ to this procedure in day surgery (LE: 1; GR: B) [88-98].

\section{Gastric Funduplication}

Currently, gastric fundoplication is mainly performed laparoscopically both in adults and children. The degree of post-operative pain has been reduced together with the duration of hospitalization. A number of good evidence based studies have been reported in adult and pediatric scientific literature suggesting the feasibility of this procedure as day-case surgery with early postoperative feeding and domiciliary pain control. However, as in the case of cholecystectomy, due to the limited use of this practice in pediatric surgery, discharge on the day of fundoplication is not yet recommended except in relation to centers with considerable experience. (LE: 4; GR: C) [99-101].

\section{Gastrostomy}

PEG (percutaneous endoscopic gastrostomy) is the gold standard to ensure enteral nutrition in neurologically impaired children. Sometimes, when PEG is inadvisable, a MAG (microlaparoscopic assisted gastrostomy) is preferred. Both procedures have been reported as suitable for day surgery, but the consensus conference proposed a more prudential approach if the surgeon is not well experienced with these procedures (LE: 3; GR: C) [102-108].

\section{SUITABLE FOR DAY SURGERY}

APPENDECTOMY

(L: 3; G.R.: B)

CHOLECYSTECTOMY

(L: 1; G.R.: B)

TO BE EVALUATED IF SUITABLE FOR DAY SURGERY

GASTRIC FUNDOPLICATIO

(L: 4; G.R.: C)

GASTROSTOMY

(L: 3; G.R.: C) 


\section{Pyeloplasty}

As for the previously mentioned more complex procedures, pyeloplasty has been reported to be suitable for a day surgery regimen either when performed with an open or laparoscopic approach. Additionally in this case the level of evidence is fairly good (LE: 4). However, the consensus conference suggestion is that careful consideration should be given and the day surgery approach should be adopted only by very experienced team. (LE: 4; GR: C) [109-114].

\section{Vesico-ureteric reflux}

The endoscopic subureteric injection of bulking materials is the most popular mini-invasive treatment for vesico-ureteric reflux. Many surgeons perform this procedure on an outpatient basis. (LE: 4; GR: B) [114].

\section{Nephrectomy}

For many years nephrectomies of non-functioning kidneys or kidneys containing masses have been reported both in adults and children. The nephrectomy is most often carried out by retroperitoneoscopy or laparoscopy. In this case, day surgery management is limited to very experienced centers.In other cases in-patient admission is recommended. (LE: 5; GR: C) [110, 115-117].

\section{SUITABLE FOR DAY SURGERY}

VESICO-URETERIC REFLUX

(L: 4; G.R.: B)

TO BE EVALUATED IF SUITABLE FOR DAY SURGERY

PYELOPLASTY

(L: 4; G.R.: C)

NEPHRECTOMY

(L: 5; G.R.: C)

\section{Anesthesia}

The aim of anesthesia is to provide a rapid smooth induction, good operation conditions and prompt recovery. Post-operative pain coverage is also desirable. The laryngeal mask airway is generally used for both spontaneous and controlled ventilation. Tracheal intubation is necessary for laparoscopic procedures and neck procedures. Local anesthesia may be planned with good local anesthetic techniques and pre-operative counseling [118].In the intra-operative phase we have compared two general anaesthesia techniques and examined the role of caudal anaesthesia in post-operative analgesia (Table. 3 ).

\section{Discharge}

Recovery from an operation depends on several factors: the duration of the operation, site of the surgery, anesthetic technique employed and age of the patient.
Table 3 Intra-operative phase

\begin{tabular}{|c|c|c|c|c|}
\hline Question & Advise & Evidence & $\begin{array}{l}\text { Grading } \\
\text { Recomandation }\end{array}$ & Literature \\
\hline $\begin{array}{l}\text { General } \\
\text { Anesthesia } \\
\text { (Inhalation } \\
\text { Anaesthesia } \\
\text { vs. TIVA) }\end{array}$ & $\begin{array}{l}\text { No differences } \\
\text { between the two } \\
\text { techniques have } \\
\text { been observed in } \\
\text { causing PONV, } \\
\text { emergence } \\
\text { agitation and } \\
\text { respiratory and } \\
\text { hemodynamic } \\
\text { complications, } \\
\text { and in influencing } \\
\text { the length of stay } \\
\text { in the recovery } \\
\text { unit. }\end{array}$ & I & $A$ & [159] \\
\hline $\begin{array}{l}\text { Caudal } \\
\text { Anesthesia } \\
\text { and post- } \\
\text { operative } \\
\text { analgesia }\end{array}$ & $\begin{array}{l}\text { Of all the loco- } \\
\text { regional } \\
\text { techniques, caudal } \\
\text { block has shown } \\
\text { the best results in } \\
\text { the short and } \\
\text { long term, } \\
\text { although } \\
\text { maintaining a } \\
\text { significant risk of } \\
\text { motor block and } \\
\text { urinary retention }\end{array}$ & I & $A$ & [160-165] \\
\hline
\end{tabular}

Ped-PADDS is a score system adapted for pediatric patients (Table. 4) [119-121]. As soon as the patient has met the discharge criteria (a score of 9/10) he/she may be discharged with written directions for home assistance and telephone numbers on-call 24/24 h. A clinical report provided to pediatrician concerned is also recommended.

\section{Conclusions}

These guidelines are based on a review of the literature in relation to different aspects of day surgery including enrollment or exclusion criteria, the surgical feasibility of the most common pediatric operations, customer satisfaction, the safety of day surgery, discharge criteria have all been reported and scored according to evidence based scientific proofs.

Table 4 Discharge phase

\begin{tabular}{lllll}
\hline Question & Advise & Evidence & $\begin{array}{l}\text { Grading } \\
\text { Recomandation }\end{array}$ & Literature \\
\hline $\begin{array}{l}\text { Discharge } \\
\text { (Ward to }\end{array}$ & $\begin{array}{l}\text { The Ped-PADSS } \\
\text { some) }\end{array}$ & $\boldsymbol{V}$ & $\boldsymbol{A}$ & [119-121] \\
& $\begin{array}{l}\text { evaluated and found } \\
\text { to be s simple, }\end{array}$ & & \\
& $\begin{array}{l}\text { practical and } \\
\text { suitable. It can also }\end{array}$ & & \\
& improve the patient \\
& flow thus reducing \\
& the duration of & & \\
& & & \\
hospitalization. & & \\
\end{tabular}


For more more than a century pediatric day surgery has been is carried out as the best practice for several common pediatric surgical procedures. However, still today, there are no good proofs supporting the feasibility of the most common pediatric day case surgery procedures on account of the absence of well designed randomized trials. Nevertheless, the widespread worldwide experience in relation to these routine operations suggests that they should be assigned a high score in the grade of recommendations scale.

The goal of these guidelines is to provide pediatric surgeons with a broader range of pediatric operations feasible in a day surgery setting with the same degree of safety as that ensured in relation to in-patient operations. The well known advantages of day surgery consist in the reduction in hospital infections, the lessening of psychological stress, the higher level of customer satisfaction, the shortening of waiting lists and the reduction in hospital costs.

\section{Acknowledgements}

The authors are grateful to Jonathan Paul Cole for the english review and to the SICP and SARNePI workshops for the reference reserch studies.

SICP workshop: Accinni A.,Appignani A., Bagnara V., Ceccarelli P., Cobellis G., Cozzi D., Del Rossi C., Esposito C., Franchella A., Gamba P., Impellizzeri P., Lelli Chiesa PL, Lima M., Marcocci G, Marte A, Messina M, Meucci D., Mognato G,Monguzzi G., Nanni L., Noccioli B., Papparella A., Parigi GB, Riccipetitoni G., Romeo C., Spagnoli A., Zampieri N.

SARNePI workshop: Astuto M, Baroncini S, Bortone L, Calamandrei M, Furlan S, Garra R, Locatelli BG, Marchesini L, Mondardini MC, Montobbio G, Presutti

P, Wolfler A, Scalisi R, Schiavi F, Pinciroli L, Sbaraglia F,Serafini GP.

\section{Funding}

Publication charges sustained by The Italian Society of Pediatric Surgery.

\section{Availability of data and materials}

Reported as references

\section{Authors' contributions}

UDL, AM and AC reviewed the surgical literature; GM, ST and MTS reviewed the anesthesiological literature; UDL wrote the manuscript: GM drafted the anesthesiological tables. All authors read and approved the final manuscript.

\section{Ethics approval and consent to participate}

Not applicable.

\section{Consent for publication}

Not applicable.

\section{Competing interests}

The authors declare that they have no competing interests.

\section{Publisher's Note}

Springer Nature remains neutral with regard to jurisdictional claims in published maps and institutional affiliations.

\section{Author details}

${ }^{1}$ Day Surgery Unit, Santobono-Pausilipon Pediatric Hospital, Napoli, Italy 2Department of Anesthesiology, San Camillo Forlanini Hospital, Roma, Italy. ${ }^{3}$ Department of Anesthesiology, Perugia University, Perugia, Italy. ${ }^{4}$ Pediatric Surgery Ospedale Salesi, Ancona, Italy. ${ }^{5}$ Department of Anesthesiology, Policlinico A. Gemelli, Roma, Italy. ${ }^{6}$ Pediatric Surgery, San Camillo Forlanini Hospital, Roma, Italy.
Received: 7 December 2017 Accepted: 23 February 2018

Published online: 12 March 2018

\section{References}

1. Istituto Superiore di sanità (ISS), Agenzia per i servizi sanitari regionali (ASSR), Centro per la valutazione dell'efficacia dell'assistenza sanitaria (CeVEAS). Come produrre, diffondere e aggiornare raccomandazioni per la pratica clinica. Manuale metodologico. Milano: Arti Grafiche Passoni; 2002. Disponibile all'indirizzo: http://www.iss.it/binary/lgmr2/cont/Manuale_PNLG. 1234439852.pdf) (1).

2. Coté CJ, Zaslavsky A, Downes JJ, Kurth CD, Welborn LG, Warner LO, et al. Postoperative apnea in former preterm infants after inguinal herniorrhaphy. A combined analysis. Anesthesiology. 1995;82(4):809-22. http:// anesthesiology.pubs.asahq.org/article.aspx?articleid=1950011.

3. Wiener ES, Touloukian RJ, Rodgers BM, Grosfeld JL, Smith El, Ziegler MM, et al. Hernia survey of the section on surgery of the American Academy of Pediatrics. J Pediatr Surg. 1996;31(8):1166-9.

4. Paediatric Surgery: Standards of care. Published by the British Association of Paediatric Surgeons, may 2002; editor D.A. Lloyd. Children's Surgery.

5. A First Class Service Report of the Paediatric Forum of The Royal College of Surgeons of England, May 2000 - Review date 2005.

6. Gabbay J, Francis L. How much day surgery? Delphic predictions Oxford Regional Health. BMJ. 1988;297:12-8.

7. Saia M, Mantoan D, Buja A, Bertoncello C, Baldovin T, Zanardo T, et al. Increased rate of day surgery use for inguinal and femoral hernia repair in a decade of hospital admissions in the Veneto Region (north- east Italy): a record linkage study. BMC Health Serv Res. 2013;13:349.

8. de Lange DH, Kreeft M, van Ramshorst GH, Aufenacker TJ, Rauwerda JA, Simons MP. Inguinal hernia surgery in the Netherlands: are patients treated according to the guidelines? Hernia. 2010;14:143-8.

9. Yeung YP, Cheng MS, Ho KL. Day-case inguinal herniotomy in Chinese children: retrospective study. Hong Kong Med J. 2002:8(4):245-8.

10. Duff M, Mofidi R, Nixon SJ. Routine laparoscopic repair of primary unilateral inguinal hernias - a viable alternative in the day surgery unit? Surgeon. 2007;5:209-12.

11. Ozdemir T, Arıkan A. Postoperative apnea after inguinal hernia repair in formerly premature infants: impacts of gestational age, postconceptional age and comorbidities. Pediatr Surg Int. 2013;29(8):801-4.

12. Welborn LG. Greenspun Anesthesia and apnea. Perioperative considerations in the former preterm infant. Pediatr Clin N Am. 1994;41(1):181-98.

13. Ueno S, Yokoyama S, Hirakawa H. Pediatric patients with inguinal hernia can be good candidates for day surgery. Nippon Geka Gakkai. 2010;10:729-32.

14. Mattila K, Hynynen M, Intensium Consortium Study Group. Day surgery in Finland: a prospective cohort study of 14 day-surgery units. Acta Anaesthesiol Scand. 2009;53:455-63.

15. Abdur-Rahman LO, Kolawole IK, Adeniran JO, Nasir AA, Taiwo JO, Odi T. Pediatric day case surgery: experience from a tertiary health institution in Nigeria. Ann Afr Med. 2009:8(3):163-7.

16. Letts M, Davidson D, Splinter W, Conway P. Analysis of the efficacy of pediatric day surgery. Can J Surg. 2001;44(3):193-8.

17. Majholm B, Engbæk J, Bartholdy J, Oerding H, Ahlburg P, Ulrik AMG, et al. Is day surgery safe? A Danish multicentre study of morbidity after 57,709 day surgery procedures B. Acta Anaesthesiol Scand. 2012;56:323-31.

18. Segerdahl M, Warrén-Stomberg M, Rawal N, Brattwall M, Jakobsson J. Children in day surgery: clinical practice and routines. The results from a nation-wide survey. Acta Anaesthesiol Scand. 2008:52:821-8.

19. IPEG. Guidelines for inguinal hernia and hydrocele. J Laparo Adv Surg Techn. 2010;20(2):11-4.

20. Clarke S. Pediatric inguinal hernia and hydrocele: an evidence-based review in the era of minimal access surgery. J Laparoendosc Adv Surg Tech A. 2010;20(3):305-9.

21. Lao OB, Fitzgibbons RJ Jr, Cusick RA. Pediatric hernias, hydroceles, and undescended testicles. Surg Clin North Am. 2012:92(3):487-504

22. Wang K. Assessment and Management of Inguinal Hernia in infants. Pediatrics. 2012;130(4):768-73.

23. Comploj E, Armin P, Lement S. Diagnosis and Management of Cryptorchidism. Eur Urol Suppl. 2012;11:2-9.

24. Ein $\mathrm{SH}, \mathrm{Nasr} \mathrm{A}$, Wales PW, Ein A. Testicular atrophy after attempted pediatric orchidopexy for true undescended testis. J Pediatr Surg. 2014:49:317-22.

25. Clark DA, Borzi PA. Laparoscopic orchidopexy for the intra-abdominal testis. Pediatr Surg Int. 1999;15(7):454-6. 
26. Safwat AS, Hammouda HM, Kurkar AA, Bissada NK, et al. Outcome of bilateral laparoscopic Fowler-Stephens orchidopexy for bilateral intraabdominal testes. Can J Urol. 2013;20(5):6951-5.

27. Sowandea OA, Takureb AO, Salakoa AA, Badmusa TA, Olajidec AO, Banjoa OO. Day case urology in a dedicated day surgery case unit in a Nigerian teaching hospital. Ambul Surg. 2009;15(2):24-6.

28. Kaye JD, Palmer LS. Single setting bilateral laparoscopic orchiopexy for bilateral intra-abdominal testicles. J Urol. 2008;180(4 Suppl):1795-9.

29. Canavese $F$, Lala $R$, Valfrè $L$, et al. Effectiveness of primary inguinal orchiopexy as treatment of non-palpable testes in the first two years of age. Minerva Pediatr. 2010;62(3):245-8.

30. Koyle MA, Oottamasathien S, Barqawi A, et al. Laparoscopic Palomo varicocele ligation in children and adolescents: results of 103 cases. J Urol. 172(4 Pt 2):1749-52.

31. Zanghí G, Di Stefano G, Furci M, et al. Surgical treatment of varicocele in day-surgery: our experience. G Chir. 2004;25(8-9):287-9.

32. Sowandea OA, Takureb AO, Salakoa AA. Day Case Urology in a Dedicated Day Case.Surgery Unit in a Nigerian Teaching Hospital. Ambul Surg. 2009; 15(2):3-11.

33. Santangelo M, Bossa F, Serra $R$, et al. Our experience with treatment of varicocele in a day-surgery protocol. G Chir. 2003;24(6-7):259-62.

34. Ammaturo C, Santoro M, Rossi R, et al. Day surgery management of varicocele with Doppler-assisted dissection at the external inguinal ring (subinguinal varicocelectomy). Chir Ital. 2005;57(5):641-7.

35. Donà $\mathrm{B}$, Cantele P, Pianalto S. Laparoscopic surgery of varicocele. Role of total endovenous anesthesia in same-day discharge. G Chir. 2000;21(10):405-8.

36. Marte A., Sabatino M.D., , Borrelli M.,et al. LigaSure Vessel Sealing System in Laparoscopic Palomo Varicocele Ligation in Children and Adolescents. J Laparoendosc Adv Surg Tech A. 2007 17(2):272-275.

37. Tagge EP, Hebra A, Overdyk F, et al. One-stop surgery: Evolving approach to pediatric outpatient surgery. J Pediatr Surg. 1999 Jan;34(1):129-32.

38. Gurnaney HG, Maxwell LG, Kraemer FW, et al. Prospective randomized observer-blinded study comparing the analgesic efficacy of ultrasoundguided rectus sheath block and local anaesthetic infiltration for umbilical .hernia repair. Br J Anaesth. 2011;107(5):790-5.

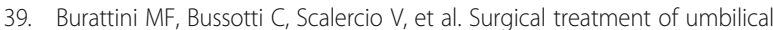
hernia in children. Our experience. Minerva Chir. 2004;59(3):277-82.

40. Barnett SJ, Frischer JS, Gaskey JA, Ryckman FC, et al. Pediatric hernia repair: 1-stop shopping. J Pediatr. 2012;47(1):213-6.

41. Hariharan $S$, Chen D, Merritt-Charles $L$, et al. Performance of a pediatric ambulatory anesthesia program - a developing country experience. Pediatr Anesth. 2006;16:388-93.

42. American Academy of Pediatrics. Report of the task force on circumcision. Pediatrics. 1989 Aug;84(2):388-91

43. Chin TW, Tsai HL, Liu CS. Modified prepuce unfurling for buried penis:a report of 12 years of experience. Asian J Surg. 2014; ISSN: 0219-3108

44. Frenkl TL, Agarwal S. Caldamone AA Results of a simplified technique for buried penis repair. J Urol. 2004;171:826-8.

45. Senaylı A, Senaylı Y. Ther a novel operative technique for concealed penis secondary to penoscrotal web: a case report. Ther Adv Urol. 2010;2:215-8.

46. Gray J, Boston VE. Glanular reconstruction and preputioplasty repair for distal hypospadias: a unique day-case method to avoid urethral stenting and preserve the prepuce. BJU. 2003:91(3):268-70.

47. Alexander KC, Leung, William LM, Robson. Hypospadias: an update. Asian J Androl. 2007:9:16-22

48. Prestipino M, Bertozzi M, Nardi N. Outpatient department repair of urethrocutaneous fistulae using n-butyl-cyanoacrylate (NBCA) a singlecentre experience. BJU Int. 2011;108:1514-7.

49. Marrocco G, Vallasciani S, Fiocca G, et al. Hypospadias surgery: a 10-year review. Pediatr Surg Int. 2004;20:200-3.

50. Ritch CR, Murphy AM, Woldu SL, et al. Overnight urethral stenting after tubularized incised plate urethroplasty for distal hypospadias. Pediatr Surg Int. 2010;26:639-42.

51. Burbige KA. Simplified postoperative management of hypospadias repair. Urology. 1994;43(5):719-21

52. Hadidi AT, Azmy AF. Hypospadias surgery. Berlin: Springer-Verlag; 2004.

53. Letts $M$, Davidson D, Splinter W. Analysis of the efficacy of pediatric day surgery. Can J Surrg. 2001;44(3):193.

54. Li WY, Chaudhry O, Reinisch JF. Guide to early surgical management of lip hemangiomas based on our experience of 214 cases. Plast Reconstr Surg. 2011;128(5):1117-24
55. Priebe CJ Jr. Outpatient management of pediatric surgical problems. Postgrad Med. 1977;62(5):132-40.

56. Isago T, Kono T, Nozaki M, et al. Ambulatory anesthesia for children undergoing laser treatment. Surg Today. 2006;36(9):765-8.

57. McDaniel DH. Cutis Cutaneous vascular disorders: advances in laser treatmen. Cutis. 1990;45(5):339-41. 346-9, 354-60;

58. Babich II, Chepurno $\mathrm{Gl}$, Babich IV. Treatment of hygroma in children. Khirurgiia. 1989;11:79-82.

59. Onathan S, Wheeler, et al. Phillip Ok-432 And Lymphatic Malformations In Children: The Starship Children's Hospital Experience. J ANZ J Surg. 2004;74: 855-8.

60. Chintapatla S, Safarani N, Kumar S. Sacrococcygeal pilonidal sinus: historical review, pathological insight and surgical options. Tech Coloproctol. 2003;7:3-8.

61. Meban S, Hunter E. Outpatient treatment of pilonidal disease. CMA J. 1982; 126:941. Neola B; Capasso S; Caruso Let al. Scarless outpatient ablation of pilonidal sinus: a pilot study of a new minimally invasive treatment, Int Wound J, 2014 Aug 14

62. Isbister WH, Prasad J. Pilonidal disease. Aust N Z J Surg. 1995;65(8):561-3.

63. Solla JA, Rothenberger DA. Chronic pilonidal disease. An assessment of 150 cases. Dis Colon Rectum. 1990;33(9):758-61.

64. Smith CM, Jones A, Dass D, Murthi G. Early experience of the use of fibrin sealant in the management of children with pilonidal sinus disease. J Pediatr Surg. 2015;50(2):320-2.

65. Rose K, Kasbekar AV, Flynn A, et al. Developing a nurse-delivered frenulotomy service. Otolaryngol Head Neck Surg. 2015;152(1):149-52.

66. Toner D, Giordano T, Handler SD. Office frenotomy for neonates: resolving dysphagia, parental satisfaction and cost-effectiveness. ORL Head Neck Nurs. 2014;32(2):6-7.

67. Sethi N, Smith D, Kortequee $S$, et al. Benefits of frenulotomy in infants with ankyloglossia. Int J Pediatr Otorhinolaryngol. 2001;77(5):762-5.

68. Rosen H, Barrios LM, Reinisch JF, Outpatient cleft lip repair, et al. Plast Reconstr Surg. 2003;112(2):381-7.

69. Arneja JS, Mitton C. Ambulatory cleft lip surgery: a value analysis. Can J Plast Surg. 2013;21(4):213-6.

70. Sohail M, Khan FA, Mir ZA, Ayub J. Comparison of ambulatory and inpatient cleft lip surgery for adults. Med Coll Abbottabad. 2010;22(2):71-4.

71. Al-Thunyan AM, Aldekhayel SA, Al-Meshal O. Ambulatory cleft lip repair. Plast Reconstr Surg. 2009;124(6):2048-53.

72. Ugburo AO, Desalu I, Adekola AF. Day case cleft lip surgery in Lagos, Nigeria Cleft Palate. Craniofac J. 2009:46(6):636-41.

73. Kim TH; Rothkopf DM, Ambulatory surgery for cleft lip repair Ann Plast Surg, 1999, 42 (4), 442-4;

74. Eaton AC, Marsh JL, Pilgram TK. Does reduced hospital stay affect morbidity and mortality rates following cleft lip and palate repair in infancy? Plast Reconstr Surg. 1994;94(7):911-5.

75. Moir CR, Blair GK, Fraser GC, Marshall RH. The emerging pattern of pediatric day-care surgery. J Pediatr Surg. 1987;22(8):743-5.

76. Rajeev P, Sutaria R, Ezzat T, Mihai R, Sadler GP. Changing Trends in Thyroid and Parathyroid Surgery over the Decade: Is Same-dayDischarge Feasible in the United Kingdom? World J Surg. 2014;38(11):2825-30.

77. Mowschenson PM, Hodin RA. Outpatient thyroid and parathyroid surgery: a prospective study of feasibility,safety, and costs. Surgery. 1995;118(6):1051-3. discussion 1053-4

78. Teoh AY, Tang YC, Leong HT. Feasibility Study Of Day Case Thyroidectomy. ANZ J Surg. 2008;78:864-6.

79. Bratu I, Laberge J-M. Day surgery for thyroglossal duct cyst excision: a safe alternative. Pediatr Surg Int. 2004:20:675-8.

80. Geller KA, Cohen D, Koempel JA. Thyroglossal duct cyst and sinuses: a 20year Los Angeles experience and lessons learned. Int J Pediatr Otorhinolaryngol. 2014;78(2):264-7.

81. Hong P. Is drain placement necessary in pediatric patients who undergo the Sistrunk procedure? Am J Otolaryngol. 2014 May;4(14) Epub ahead of print] PMID: 24888796

82. Frazee RC, Abernathy SW, Davis M. Outpatient laparoscopic appendectomy should be the standard of care for uncomplicated appendicitis. J Trauma Acute Care Surg. 2014;76(1):79-82.

83. Cross W, Kowdley GC. Laparoscopic Appendectomy for Acute Appendicitis: A Safe Same-day Surgery Procedure? Am Surg. 2013;79:802-5 89.

84. Alkhoury F, Burnweit C, Malvezzi L. A prospective study of safety and satisfaction with same-day discharge after laparoscopic appendectomy for acute appendicitis. J PedSurg. 2012;47:313-6. 
85. Alkhoury F, Malvezzi L, Knight CG. Routine same-day discharge after acute or interval appendectomy in children a prospective study. Arch Surg. 2012; 147(5):443-6.

86. Grewal H, Sweat J, Vazquez WD. Laparoscopic appendectomy in children can be done as a fast-track or same-day surgery. JSLS. 2004;8(2):151-4.

87. Akkoyun I. Outpatient laparoscopic appendectomy in children: a single center experience with 92 cases. Surg Laparosc Endosc Percutan Tech. 2013; 23(1):49-50.

88. Vuilleumier H, Halkic N. Laparoscopic Cholecystectomy as a Day Surgery Procedure: Implementation and Audit of 136 Consecutive Cases in a University Hospital. World J Surg. 2004;28:N 8.

89. Harboe KM, Bardram L. Nationwide quality improvement of cholecystectomy: results from a national database. Int J Qual Health Care. 2011;23(5):565-73.

90. Psaila J, Agrawal S, Fountain U, et al. Day-surgery laparoscopic cholecystectomy: factors influencing same-day discharge. World J Surg. 2008;32:76-81

91. Goulart A, Delgado M. Antunes laparoscopic cholecystectomy in ambulatory: what results? Acta Medica Port. 2013;26(5):564-8

92. Agarwal P, Bagdi RKJ. Day case laparoscopic cholecystectomy in children: a review of 11 cases. Indian Assoc Pediatr Surg. 2014;19(2):61-4.

93. Harboe KM, Bardram L. The quality of cholecystectomy in Denmark: outcome and risk factors for 20,307 patients from the national database. SurgEndopsc. 2011;25(5):1630-41.

94. Jawaheer G, Evans K, Marcus R. Day-case laparoscopic cholecystectomy in childhood: outcomes from a clinical care pathway. Eur J Pediatr Surg. 2013; 23(1):57-62.

95. Gurusamy K, Junnarkar S, Farouk M. Meta-analysis of randomized controlled trials on the safety and effectiveness of day-case laparoscopic cholecystectomy. Br J Surg. 2008;95(2):161-8

96. Barthelsson C, Lützén $\mathrm{K}$, Anderberg $\mathrm{B}$, et al. Patients' experiences of laparoscopic cholecystectomy in day surgery. J Clin Nurs. 2003;12(2):253-9.

97. Vaughan J, Gurusamy KS, Davidson BR. Day-surgery versus overnight stay surgery for laparoscopic cholecystectomy (Review).Copyright (C: The Cochrane collaboration. Published by JohnWiley \& Sons, Ltd; 2013.

98. Gurusamy KS, Junnarkar S, Farouk M. Day-case versus overnight stay in laparoscopic cholecystectomy. Cochrane Database Syst Rev. 2008;23(1):CD006798.

99. Mariette C, Pessaux P. Ambulatory laparoscopic fundoplication for gastroesophageal reflux disease: a systematic review. Surg Endosc. 2011;25: 2859-64.

100. Agrawal S, Super P. Laparoscopic Heller myotomy for achalasia: changing trend toward "true" day-case procedure. J Laparoendosc Adv Surg Tech A. 2008;18(6):785-8

101. Banieghbal B., And Beale P., Day-Case Laparoscopic Nissen Fundoplication in Children. J Lap Adv Surg Tech. 2007;17: 3.

102. Boll J, Daly S, Smolevitz J, et al. Safety and Efficsacy of Outpatient Percutaneous Endoscopic Gastrostomy for Patients with Head and Neck Cancer. Am Surg. 2015:81(2):215-6.

103. Turial S, Schwind M, Engel V, et al. Microlaparoscopic-Assisted Gastrostomy in Children: Early Experiences with Our Technique .J Lap Adv Surg Tech. 2009, 19(1), 229-231.

104. Wilhelm SM, Ortega KA, Stellato TA. Guidelines for identification and management of outpatient percutaneous endoscopic gastrostomy tube placement. Am J Surg. 2010:199(3):396-9.

105. de Souza e, Mello GF, Lukashok HP, Meine GC. Outpatient percutaneous endoscopic gastrostomy in selected head and neck cancer patients. Surg Endosc. 2009;23(7):1487-93.

106. Best $\mathrm{C}$, Hitchings $\mathrm{H}$. Day case gastrostomy placement for patients in the community. Br J Community Nurs. 2010;15(6):272-8.

107. Srinivasan R, Irvine T, Dalzell M. Indications for percutaneous endoscopic gastrostomy and procedure-related outcome. J Pediatr Gastroenterol Nutr. 2009;49(5):584-8.

108. Mandal A, Steel A, Davidson AR. Day-case percutaneous endoscopic gastrostomy: a viable proposition? Postgrad Med J. 2000;76(893):157-9.

109. Stewart AF, Smith DP. Performance of open renal and bladder surgery at a freestanding pediatric surgery center. J Urol. 2011;186(1):252-6.

110. Sprunger JK, Reese $C T$, Decter RM. Can standard open pediatric urological procedures be performed on an outpatient basis? J Urol. 2001:166(3):1062-4.

111. Mohamed M, Hollins G, Eissa M. Experience in performing pyelolithotomy and pyeloplasty in children on day-surgery basis. Urology. 2004;64(6):1220-2.
112. Oberlin DT, McGuire BB, Pilecki M, et al. Contemporary national surgical outcomes in the treatment of ureteropelvic junction obstruction. Urology. 2015;85(2):363-7.

113. Ilie CP, Luscombe CJ, Smith I, Boddy J, et al. Routine day-case laparoscopic pyeloplasty: a paradigm shift? J Endourol. 2011;25(5):797-801.

114. Tekgul S, Dogan HS, Hoebeke R, Kocvara JM, Nijman C, Radmayr R. Stein guidelines on pediatric urology- European Association of Paediatric Urology. Pediatr Urol. 2014;71:1-130.

115. Ilie CP, Luscombe CJ, Smith I. Day case laparoscopic nephrectomy. J Endourol. 2011;25(4):631-4.

116. Tradaguilla AR, Romero AR, Parente A. Fast-track in pediatric urologic surgery: pronephrectomy. Cir Pediatr. 2013;26(2):81-5.

117. Ilie CP, Luscombe CJ, Smith I, et al. Day case laparoscopic nephrectomy: initial experience. J Med Life. 2011;4(1):36-9.

118. Upadhyaya M, Lander A. Day-case surgery in children. Surgery (Oxford). 2013;31(3):101-46

119. Ead $H$. From Aldrete to PADSS: reviewing discharge criteria after ambulatory surgery. J Perianesth Nurs. 2006;21(4):259-67.

120. Biedermann S, Wodey E, De La Brière F, Pouvreau A, Ecoffey C. Paediatric discharge score in ambulatory surgery. Ann Fr Anesth Reanim. 2014;33(5):330-4.

121. Moncel JB, Nardi N, Wodey E, Pouvreau A, Ecoffey C. Evaluation of the pediatric post anesthesia discharge scoring system in an ambulatory surgery unit. Paediatr Anaesth. 2015 Jun;25(6):636-41.

122. Brennan LJ, Prabhu AJ. Paediatric day-case anaesthesia. Contin Educ Anaesth Crit Care Pain. 2003:3:134-8.

123. Tremlett M. Day surgery for children. Anaesth Int Care Med. 2003;4(12):399-401.

124. Awad IT, Moore M, Rushe C, Elburki A, O'Brien K, Warde D. Unplanned hospital admission in children undergoing day-case surgery. Eur Anaesthesiol. 2004;21(5):379-83.

125. Hughes JM, Callery P. Parents' experiences of caring for their child following day case surgery: a diary study. J Child Health Care. 2004;8(1):47-58.

126. Shetty N, Sethi D. Paediatric anaesthesia for day surgery. Anaesthesia Tutorial Of The Week (ATOTW) 203. 2010. http://www.frca.co.uk/Documents/ 203\%20Anaesthesia\%20for\%20paediatric\%20day\%20surgery.pdf.

127. Haute Autorité de Santé (HAS), Agence Nationale d'appui à la performance des établissements de santé et médico-sociaux (ANAP). Together for the development of day surgery. Paris: Tecnology Report Haute Autorité de Santé; 2013. https://www.has-sante.fr/portail/upload/docs/application/pdf/ 2013-11/day_surgery_-_an_overview.pdf.

128. Everett L. How young is the youngest infant for outpatient surgery? In: Fleisher $L$, editor. Evidence-based practice of anesthesiology. 1st ed. Oxford: Saunders; 2004. p. 523-8.

129. Bajaj P. What is the youngest age appropriate for outpatient surgery? Indian J Anaesthe. 2009;53:5-6. https://www.ncbi.n/m.nih.gov/pmc/articles/PMC2900027/.

130. Taylor D, Thomas M. Day surgery for children. Anaesth Intensive Care Med. 2010;11(6):210-3.

131. Navaratnarajah J, Thomas ML. Day surgery for children. Anaesth Int Care Med. 2013;14(6):232-6.

132. Short J, Bew S, Kirton C, Sanderson S, Barker J. Issues in Paediatric day surgery. London: BADS; 2007. http://daysurgeryuk.net/en/shop/handbooks/ ?\&page $=5$.

133. SARNePI. Consensus Conference Pediatric Day Surgey. Torino; 2014.

134. Parnis SJ, Barker DS, Van Der Walt JH. Clinical predictors of anaesthetic complications in children with respiratory tract infections. Paediatr Anaesth. 2001;11(1):29-40. http://onlinelibrary.wiley.com/doi/10.1046/j.1460-9592. 2001.00607.x/abstract.

135. Tait AR, Malviya S, Voepel-Lewis T, et al. Risk factors for perioperative adverse respiratory events in children with upper respiratory tract infections. Anesthesiology. 2001;95(2):299-306. http://anesthesiology.pubs.asahq.org/ article.aspx?articleid=1945163.

136. Tait AR, Malviya S. Anesthesia for the child with an upper respiratory tract infection: still a dilemma? Anesth Analg. 2005;100(1):59-65. http://journals. Iww.com/anesthesia-analgesia/pages/articleviewer.aspxyear $=2005 \& i s s u e=$ 01000\&article $=00011 \&$ type $=$ abstract.

137. Davidson AJ, Morton NS, Arnup SJ, de Graaff JC, Disma N, Withington DE, et al. General anesthesia compared to spinal anesthesia (GAS) consortium Apnea after awake regional andGeneral anesthesia in infants: the general anesthesia compared to spinal anesthesia study-comparing apnea and neurodevelopmental outcomes, a randomized controlled trial. Anesthesiology. 2015;123(1):38-54. http://anesthesiology.pubs.asahq.org/ article.aspx?articleid $=2294589$ 
138. Walther-Larsen S, Rasmussen LS. The former preterm infant and risk of postoperative apnoea: recommendations form management. Acta Anaesthesiol Scand. 2006;50(7):888-93. http://onlinelibrary.wiley.com/doi/10.1111/j.13996576.2006.01068.x/epdf.

139. Wilkinson K A, Brennan L, Rollin A-M. Paediatric Anaesthesia services in guidelines for the prevision of anaesthetic services 2016. http://www.rcoa. ac.uk/system/files/GPAS-2016-10-PAEDIATRICS.pdf.

140. Lipp A. Anaesthesia services for day surgery 2016 in Guidelines for the prevision of anaesthetic services; 2014. p. 25. https://www.rcoa.ac.uk/system/ files/GPAS-2016-06-DAYSURGERY.pdf.

141. Hackel A, Badgwell JM, Binding RR, Dahm LS, Dunbar BS, Fischer CG, et al. Guidelines for the pediatric perioperative anesthesia environment. American Academy of Pediatrics. Section on anesthesiology. Pediatrics. 1999;103(2): 512-5. http://pediatrics.aappublications.org/content/103/2/512.long.

142. Committee on Standards and Practice Parameters, Apfelbaum JL, Connis RT, Nickinovich DG, American Society of Anesthesiologists Task Force on Preanesthesia Evaluation, Pasternak LR, Arens JF, Caplan RA, Connis RT, Fleisher LA, Flowerdew R, et al. Practice advisory for preanesthesia evaluation: an updated report by the American Society of Anesthesiologists Task Force on Preanesthesia Evaluation. Anesthesiology. 2012;116(3):522-38. http://anesthesiology.pubs.asahq.org/article.aspx?articleid=2443414.

143. Serafini G, Ingelmo PM, Astuto M, Baroncini S, Borrometi F, Bortone L, et al. Italian Society of Pediatric and Neonatal Anesthesia and intensive care (SARNePI). Preoperative evaluation in infants and children: recommendations of the Italian Society of Pediatric and Neonatal Anesthesia and intensive care (SARNePI). Minerva Anestesiol. 2014;80(4):4619. Review. http://www.minervamedica.it/it/riviste/minerva-anestesiologica/ articolo.php?cod=R02Y2014N04A0461

144. Mangia G, Presutti P, Antonucci A, Bianco F, Bonomo R, Ferrari P. Diagnostic accuracy of anesthesiology evaluation timing: the 'One-stop Anesthesia' in pediatric day-surgery. Paediatr Anaesth. 2009;19(8):764-9. http:// onlinelibrary.wiley.com/doi/10.1111/j.1460-9592.2009.03080.x/epdf.

145. Mangia G, Bianco F, Bonomo R, Di Caro E, Frattarelli E, Presutti P. Willingness to pay for one-stop anesthesia in pediatric day surgery. Ital J Pediatr. 2011; 37:23. https://www.ncbi.nlm.nih.gov/pmc/articles/PMC3121670/.

146. Czoski-Murray C, Lloyd Jones M, McCabe C, Claxton K, Oluboyede Y, Roberts $\mathrm{J}$, et al. What is the value of routinelytesting full blood count, electrolytes and urea, and pulmonary function testsbefore elective surgery in patients with no apparent clinical indication and insubgroups of patients with common comorbidities: a systematic review of theclinical and cost-effective literature. Health Technol Assess. 2012;16(50):i-xvi, 1-159. https://www.ncbi. nlm.nih.gov/pubmedhealth/PMH0051890/.

147. Le Roux C, Lejus C, Surbleb M, Renaudin M, Guillaud C, de Windt A, et al. Is haemostasis biological screening always useful before performing aneuraxial blockade in children? Paediatr Anaesth. 2002;12(2):118-23.

148. Bonhomme F, Ajzenberg N, Schved JF, Molliex S, Samama CM, French Anaesthetic and intensive care committee on evaluation of routine preoperative testing, French Society of Anaesthesia and Intensive Care. Preinterventional haemostatic assessment: guidelines from the French society of Anaesthesia and intensive care. Eur J Anaesthesiol. 2013;30(4):142-62. http://journals.Iww.com/ejanaesthesiology/Fulltext/2013/04000/Pre_ interventional_haemostatic_assessment_.2.aspx.

149. Castellano P, López-Escámez JA. American Society of Anesthesiology classification may predict severe post-tonsillectomy haemorrhage in children. J Otolaryngol. 2003;32(5):302-7.

150. Biss TT, Blanchette VS, Clark DS, Bowman M, Wakefield CD, Silva M, et al. Quantitation of bleeding symptoms in children with von Willebrand disease: use of a standardized pediatric bleeding questionnaire. J Thromb Haemost. 2010;8(5):950-6. Disponibile alla pagina: http://onlinelibrary.wiley. com/doi/10.1111/j.1538-7836.2010.03796.x/epdf.

151. Biss TT, Blanchette VS, Clark DS, Wakefield CD, James PD, Rand ML. Use of a quantitative pediatric bleeding questionnaire to assess mucocutaneous bleeding symptoms in children with a platelet function disorder. J Thromb Haemost. 2010;8(6):1416-9. http://onlinelibrary.wiley.com/doi/10.1111/j. 15387836.2010.03846.x/abstract.

152. Licameli GR, Jones DT, Santosuosso J, Lapp C, Brugnara C, Kenna MA. Use of a preoperative bleeding questionnaire in pediatric patients who undergo adenotonsillectomy. Otolaryngol Head Neck Surg. 2008;139:546-50. http:// journals.sagepub.com/doi/pdf/10.1016/j.otohns.2008.06.021.
153. Brady M, Kinn S, Ness V, O'Rourke K, Randhawa N, Stuart P. Preoperative fasting for preventing perioperative complications in children. Cochrane Database Syst Rev. 2009;4:CD005285.

154. Schmidt AR, Buehler P, Seglias L, Stark T, Brotschi B, Renner T, et al. Gastric $\mathrm{pH}$ and residual volume after 1 and $2 \mathrm{~h}$ fasting time for clear fluids in children. Br J Anaesth. 2015;114(3):477-82. https://academic.oup.com/bja/ article-lookup/doi/10.1093/bja/aeu399.

155. Smith I, Kranke P, Murat I, Smith A, O'Sullivan G, Søreide E, Spies C, in't Veld $B$, European Society of Anaesthesiology. Perioperative fasting in adults and children: guidelines from the European Society of Anaesthesiology. Eur J Anaesthesiol. 2011;28(8):556-69. http://journals.Iww.com/ejanaesthesiology/ Fulltext/2011/08000/Perioperative_fasting_in_adults_and_children_.4.aspx.

156. Lambert E, Carey S. Practice guideline recommendations on perioperative fasting: a systematic review. JPEN J Parenter Enteral Nutr. 2016:40(8):1158-65.

157. Eberhart LH, Geldner G, Kranke P, Morin AM, Schäuffelen A, Treiber H, et al. The development and validation of a risk score to predict the probability of postoperative vomiting in pediatric patients. Anesth Analg. 2004;99(6):1630 7. http://journals.Iww.com/anesthesiaanalgesia/Fulltext/2004/12000/The_ Development_and_Validation_of_a_Risk_Score_to.11.aspx.

158. Gan TJ, Diemunsch P, Habib AS, Kovac A, Kranke P, Meyer TA et al; Society for Ambulatory Anesthesia. Consensus guidelines for the management of postoperative nausea and vomiting. Anesth Analg. 2014;118(1):85-113. http://journals.Iww.com/anesthesiaanalgesia/Fulltext/2014/01000/ Consensus_Guidelines_for_the_Management_of.13.aspx.

159. Ortiz AC, Atallah AN, Matos D, da Silva EM. Intravenous versus inhalational anaesthesia for paediatric outpatient surgery. Cochrane Database Syst Rev. 2014;2:CD009015.

160. Polaner DM, Taenzer AH, Walker BJ, Bosenberg A, Krane EJ, Suresh S. Pediatric regional anesthesia network (PRAN): a multi-institutional study of the use and incidence of complications of pediatric regional anesthesia. Anesth Analg. 2012;115(6):1353-64. http://journals.Iww.com/anesthesiaanalgesia/Fulltext/2012/12000/Pediatric_Regional_Anesthesia_Network_ PRAN A.15.aspx

161. Ivani G, Suresh S, Ecoffey C, Bosenberg A, Lonnqvist PA, Krane E. The European Society of Regional Anaesthesia and Pain Therapy and the American Society of Regional Anesthesia and Pain Medicine joint committee practice advisory on controversial topics in pediatric regiona anesthesia. Reg Anesth Pain Med. 2015;40(5):526-32. http://journals.lww. com/rapm/Fulltext/2015/09000/The_European_Society_of_Regional_ Anaesthesia_and.11.aspx.

162. Bosenberg A. Benefits of regional anesthesia in children. Paediatr Anaesth. 2012;22(1):10-8.

163. Neal JM, Bernards CM, Butterworth JF 4th, Di Gregorio G, Drasner K, Hejtmanek MR, et al. ASRA practice advisory on local anesthetic systemic toxicity. Reg Anesth Pain Med. 2010;35(2):152-61. http://journals.lww.com/ rapm/Fulltext/2010/03000/ASRA_Practice_Advisory_on_Local_Anesthetic.7. aspx.

164. Ecoffey C, Lacroix F, Giaufré E, Orliaguet $G$, Courrèges $P$, Association des Anesthésistes Réanimateurs Pédiatriques d'Expression Française (ADARPEF). Epidemiology and morbidity of regional anesthesia in children: a follow-up one-year prospective survey of the French-language Society of Paediatric Anaesthesiologists (ADARPEF). Paediatr Anaesth. 2010;20(12):1061-9.

165. Shanthanna H, Singh B, Guyatt G. A systematic review and meta-analysis of caudal block as compared to noncaudal regional techniques for inguinal surgeries in children. Biomed Res Int. 2014;2014:890626. https://www.ncbi. nlm.nih.gov/pmc/articles/PMC4139076/. 